\title{
Expanding electricity access to all in Nigeria: a spatial planning and cost analysis
}

\author{
Sanusi Ohiare
}

\begin{abstract}
Background: The challenge of lack of access to electricity especially in the rural areas of Nigeria is further compounded by the lack of cogent electrification plans. A fairly reasonable electrification plan should be able to model least-cost electrification technologies to be employed and give an estimate of investments required over a given period of time. The 2012 United Nation's declaration of 'International Year of Sustainable Energy for All' highlights the importance of such studies and innovations, towards attracting funds from various sources for sustainable electrification projects.

Methods: With the aid of a spatial electricity planning model called the 'Network Planner (NP)', this study identifies the appropriate least-cost electrification supply mode (grid, mini-grid and/or off-grid) and provides cost estimates for achieving universal energy access in Nigeria by 2030.

Results: Results from this research show that by the end of the 17-year planning period (2013 to 2030), 98\% of currently unelectrified communities will be viable for grid expansion, while only $2 \%$ will be mini-grid compatible. An estimated total cost of US\$34.5 billion investment is required to provide electricity access to a total number of 28.5 million households (125 million people) by 2030. The analysis was carried out for the 36 states of Nigeria as well as the entire country, using data from the 774 local government areas (LGAs) of Nigeria.

Conclusions: This paper provides the foundation for the Nigerian Rural Electrification Agency (NREA) to develop an electrification plan as well as involve all stakeholders in carrying out direct surveys towards generating a database for rural electrification status in Nigeria.
\end{abstract}

Keywords: Electricity access; Rural electrification; Nigeria; Spatial electricity planning

\section{Background}

Despite the importance and contributions of electricity to every facet of human endeavour such as health, education, agriculture and households, access to it remains elusive in most parts of the developing world [1]. The most widely quoted figure for those people living in developing countries without access to electricity services is estimated to be over 1.3 billion [2], 85\% of them reside in rural areas of Asia and Sub-Saharan Africa. According to the International Energy Agency (IEA) [3], SubSaharan Africa only has an electrification rate of $32 \%$ and, if no concerted efforts and policies are put in place immediately, it is feared that in 2030, the number of people without access to electricity will only slightly drop to 1.2 billion as projected in 2030 by IEA [4].

Correspondence: sanusiohiare@gmail.com

Nigerian Energy Support Programme (NESP), Deutsche Gesellschaft für, Internationale Zusammenarbeit GmbH, German Agency for International Cooperation (GIZ), No. 2, Dr. Clement Isong Street, Asokoro, Abuja, Nigeria
Majority of those lacking access to energy (70\%) reside in just a handful of countries including Nigeria, where the rural population is the most affected [5]. Data provided by IEA [3] shows that Nigeria, who ranks seventh in world population, cannot provide access to electricity to an estimated 85 million people in both the urban and rural areas, which accounts for $42 \%$ of her population in 2013. Sub-Saharan Africa also accounts for the 10 least electrified countries in the world, even though the South Asian region has the highest number of population without access to electricity.

The Social-Economic survey conducted by the National Bureau of Statistics [6] provides some information about the percentage distribution of households by states and various sources of electricity supply in Nigeria in 2009. Data from the survey shows that an average of $35.3 \%^{\mathrm{a}}$ of households lacked access to electricity that year. The survey also shows that the use of renewable energy (especially

\section{实}

(c) 2015 Ohiare; licensee Springer. This is an Open Access article distributed under the terms of the Creative Commons Attribution License (http://creativecommons.org/licenses/by/4.0), which permits unrestricted use, distribution, and reproduction in any medium, provided the original work is properly credited. 
solar energy) for rural electrification is yet to be taken seriously, as there is near absence of solar electricity in Nigeria in the survey year as well as the low rural electrification rate provided.

The NBS survey shows that almost $50 \%$ of the states in Nigeria have more than $50 \%$ of people without access to electricity, which brings to fore the challenge of lack of electricity access in various parts of Nigeria $[7,8]$. Private generators are also observed to be playing an increasingly important role in the electricity supply mix of Nigeria especially for the rich, as the number of private generators used to supplement Power Holding Company of Nigeria (PHCN) supply rose from $5.8 \%$ in 2007 to $7.6 \%$ in 2009 [6].

It is also evident from the survey that while the challenge of lack of electricity supply is prevalent across Nigeria, the Northern part of the country suffers more. The highest number of households without access to any form of electricity supply in 2009 was recorded in Taraba state (Northeast Nigeria) and put at $81.3 \%$. Lagos state (Southwest Nigeria) on the other hand recorded the smallest percentage of households without access to electricity at $6.1 \%$.

Electricity generation and distribution have now been privatized in Nigeria. Thus, electricity expansion plans are focused on areas already covered by the grid or close to the grid, based on the business plans of the distribution companies. This makes electricity access to rural areas slow and creates a mix-up as to how to proceed with rural electrification [9].

Although the Nigerian Rural Electrification Agency (NREA) was created to bridge the gap, it currently lacks any spatial electricity planning study that gives a detailed analysis of which mode of electricity supply (grid, minigrid and off-grid) to be used in different parts of Nigeria, as well as costs of expanding access to all areas currently without access. This has affected electrification expansion planning and prioritization. This paper fills this gap through a detailed spatial electricity planning and costing model using the Network Planner (NP) model, which is the first attempt at spatial electricity planning in Nigeria.

The two questions underpinning this study are as follows:

1. What combination of grid, mini-grid and off-grid electricity supply options should Nigeria adopt in providing universal electricity access to her diverse rural areas by 2030 ?

2. What is the investment requirement towards achieving universal electrification in Nigeria by 2030?

The NP model used data from the 774 local government areas (LGAs) of Nigeria to answer the aforementioned questions. The model was applied at the national level as well as analysed at the disaggregated state levels, for each of the 36 states of Nigeria and the capital city Abuja. A sensitivity analysis of base results was also carried out to see the effects of changes in household demand, diesel prices and solar panels.

The paper is organized as follows: the second section describes the Network Planner model and its application in Nigeria; the Results and discussion section presents the results and analysis; the Sensitivity analysis section provides some sensitivity analysis, while the Conclusions section concludes the paper.

\section{Methods}

\section{Model description and application in Nigeria}

The Network Planner (NP) ${ }^{\mathrm{b}}$ model is a decision support tool that determines the least-cost technology - either grid electrification or an off-grid alternative - to connect each population centre, which is referred to as a demand node ${ }^{c}$ in this research. The NP model uses data on electricity costs and demand, population and other socio-economic data to estimate detailed cost projections for three electrification technology options: (a) off-grid (solar PV panel supported by small diesel generator for production use), (b) mini-grid (solely on diesel generator) and (c) grid electrification (internal grid plus external connection to the existing grid network). The NP model then recommends the most viable and optimal cost-effective option for electrifying an area within a fixed time horizon. This enables planners to have an insight into areas that grid expansion is more viable option and where other decentralized options offer the cost-optimized alternatives for electrification purposes.

The model also combines a Geographic Information System (GIS) tool to execute spatial processing and investigation, using relevant population and geospatial data, and algorithmically creates a detailed, cost-optimized electricity proposal, including a map of the estimated grid extension, areas to use off-grid technologies, and other associated costs. Based on available data, the model can generate results at any geographical scale - national, state or local levels.

In order to obtain a reasonable estimate of the total cost given the vastness of the Nigerian landmass, diversity of physical terrain, diversity of climatic conditions and unavailability of community-based data, we simplify the number of demand nodes from thousands of rural communities/villages to all the 774 LGAs in the 36 states of Nigeria where access to electricity is lacking with an inherent assumption that the heterogeneity of communities in a particular local government area will be minimal. This allows for the use of available demographic and socio-economic data that are available at the LGA levels.

Results derived from the 'NP model' can be implanted on a map to show various areas with their proposed and existing grid network linking the LGAs, as well as their proposed targeted electrification. The NP model also allows for 
various scenario and sensitivity analysis to be performed. By changing input variables such as prices and demand, and running different scenarios, the 'NP model' enables planners to understand the effect this would have on electrification costs.

The main aim of using this model is to estimate the cost of expanding electricity access to the millions of households currently without access in Nigeria and select the least-cost technology to achieve this in different LGAs. As noted by [10], 'The model is not meant to replace detailed engineering analyses of grid rollout, including load-flow analysis, which would be needed as part of the implementation process, so it cannot be used as a stand-alone implementation tool'.

Other models that were initially considered for this research are HOMER Micro-optimization software and the RETScreen Model. HOMER and RETScreen work at project levels whereas NP works at regional or macro levels. The first two are for project viability analysis whereas NP is for network expansion planning. HOMER is computer optimization software used in designing micro-power systems for effective evaluation of different renewable energy and hybrid systems. HOMER does more of technical analysis and is based on life cycle costs of the system's life span. Although it allows for the modelling of grid-connected and off-grid systems, it focuses on power generation and also allows for simulation and sensitivity analysis. RETScreen on the other hand allows you decide whether or not a proposed renewable energy, energy efficiency or cogeneration projects are financially viable or not. It also allows for sensitivity and risk analysis, cost analysis and emission analysis; thus, it is biased towards renewable energy systems.

\section{Estimation of projected population and demand}

The electricity demand in each LGA is estimated using data on a number of households and household energy use in each LGA. The basic household energy demand in rural communities is for cooking, lighting, heating, water pumping, agro-related purposes and to power gadgets used in micro-enterprises [11].

In every demand node, the increase in demand for electricity is subject to economic and/or population growth(s). Thus demand nodes with high population and high economic growth rates have higher electricity demands, and vice versa. In the same way, households in cities/towns and large settlements tend to have higher electricity demand than those in the rural areas.

Thus, taking all these factors into consideration, data for the base year (2013) urban and rural population growth rates from the NPC, population of people without access to electricity and geospatial data (latitude and longitude coordinates) of all the 774 LGAs of Nigeria are processed and uploaded into the model. In projecting the population to the final year of planning horizon (2030), the model applies various population growth rates to urban and rural areas based on the user-defined urban threshold (i.e. the value of a size of population below which a demand node is considered rural and above which it is urban).

The model then applies the population growth rate every successive year till the last year of the planning horizon, including provisions allowing for a rural community to start up with the rural growth rate and end up with the urban growth rate as its population outgrows the urban-rural threshold.

The blend of Nigeria's economic growth rate, mean household size, peak demand data, population growth rate (rural and urban) and the base year electricity unit demands of the communities is used to project the total electricity demands needed at the end of the specified time horizon.

\section{Estimation of cost for each technology}

Detailed cost components of the chosen electrification technologies such as the cost of low voltage (LV) lines, medium voltage $(\mathrm{MV})^{\mathrm{d}}$ lines, transformers, diesel fuel per litre, diesel generators, solar panels and solar batteries, plus recurring costs, comprising operation and maintenance are required by the model. The model also needs interest rate per year to be used to determine the discounted costs for each technology option. This was combined with other cost components to estimate the projected cost of electrification for each technology choice based on the projected electricity demands at the completion of the planning time limit.

\section{Selection of least-cost technology}

Given the projected electricity demand for each demand node over the specified time horizon (2013 to 2030), the model first calculates the total costs of electrification comprising all preliminary and recurrent expenditures for the three different electrification technology alternatives.

The select three technologies are (a) off-grid which is defined as a hybrid of solar photovoltaic (PV) and diesel generator for household and productive use, respectively, (b) mini-grid which is defined as diesel generator plant with LV supply for all types of demand (productive, household, social infrastructure, etc.) and (c) grid electrification is sub-divided into two grid connections and costs groupings (internal and external) [12]. While the 'internal' grid connection involves cost of transformers, secondary MV lines, ${ }^{\mathrm{e}} \mathrm{LV}$ lines and internal house wiring for connecting households, institutions and other structures within the demand node, the 'external' grid connection entails extending the MV lines from a transformer in the demand node to the closest MV grid network. 
Subsequently, the discounted costs of the two 'stand alone' technology options, i.e. the off-grid and mini-grid, are compared, and the one with the least cost is selected. The selected stand-alone option is further compared with the discounted cost of only the internal element of grid connection costs of the demand node. If the leastcost stand-alone option has a lower cost than the internal component of the grid cost, then the grid connection is regarded as the unviable option for the demand node, and the model selects the least-cost standalone technology as the optimal electrification option.

However, if the cost of the internal grid component is lower than the least-cost stand-alone alternative, then the difference forms the budget available for the external part of the grid connection costs for such demand node. This is the MV line, which connects to the nearest grid location. By dividing this value by the cost of MV line per metre, the model obtains a key decision metric, 'MVmax' for each demand node. The MVmax, expressed in metres, denotes the maximum length of MV line which can be connected for each demand node before the cost of grid extension exceeds the cost of the leastcost stand-alone option. The metric is specific to each demand node and provides a basic estimate of how far the existing MV line network can be cost-effectively extended to reach this demand node. The household cost of connection is not considered as it is an internal cost.

Lastly, the model uses geospatial algorithm to compare these MVmax values with the actual distances between the location of unconnected communities (identified by latitude and longitude coordinates) and identifies those sites with MVmax values that justify grid connection. Those communities that are selected, indicating that grid extension is the most cost-effective technology to electrify a community, are recommended for grid connection by the model; in other words, they are 'grid-compatible'. Those demand nodes beyond the MVmax values are on the other hand recommended for electrification using the least-cost stand-alone alternative.

It should be noted here that Nigeria has various energy resources (renewable and conventional) and could have easily tapped into its extensive natural resources such as biomass, hydro (mini and micro), gas, wind and biomass for this research. The choice of solar/diesel hybrid for the off-grid option and diesel generator plant for the mini-grid stems from the fact that their costs and resources are fairly well available and understood, suffice to say that the technology can be easily applied in every part of Nigeria.

Specifically, biomass gasifiers which was a technology of choice that was closely considered given the huge agricultural activities going on in rural Nigeria, had to be dropped due to its limited success from the experiences of other countries in its usage especially in India
[13] and Sri Lanka [14]. Technology management and the poor quality of the product are reasons attributed to its failure [15].

\section{Estimation of investment cost/requirement using the NP model}

It is important to point out specifically which part of this model deals with the central question of estimating the investment costs and financing requirement of rural electrification in Nigeria.

In the course of estimating the different costs of the select three technology options (off-grid, mini-grid and grid), as well as comparing them to see the least-cost/ most viable option, the Network Planner model performs a financial analysis. It does this by estimating the net present value (NPV) of the 17-year ${ }^{\mathrm{f}}$ discounted capital and maintenance costs for each technology option based on the unit costs of appropriately sized equipment.

The cost of the technology ${ }^{g}$ for all cases includes installation of equipment and transportation. For grid extension, capital costs cover LV line to connect households and institutions, MV line and transformers, poles and other household equipment such as lamps and wire. However, costs do not include generation, institutional capacity building and reinforcement of the existing distribution network.

The diesel mini-grid cost structure is similar to national grid extension but includes the cost of an appropriately sized diesel generator for the demand node. Solar PV plus diesel capital costs include solar panels and batteries for domestic demand and a diesel generator for productive demand. Note that since the decentralized options are stand-alone systems of distribution, costs associated with generating electricity using solar PV and/or diesel generator are included. In the case of grid extension, generation costs are included indirectly through the cost of MV electricity purchases.

Therefore, the above financial analysis performed by the model gives us a guide as to the investment costs/financing requirement of rural electrification in Nigeria.

\section{Results and discussion}

\section{Base scenario}

The following assumptions were used for the base scenario: 100\% electrification rate by 2030, with 2013 being the base year; current pump price of diesel fuel per litre of US\$0.96, 1,460-h operation of diesel mini-grid per year; average household demand of $330 \mathrm{kWh}$ per year; a mean inter-household distance of 25 metres and a rural-urban population threshold of 20,000. All input model data were obtained in 2013 except the population data that was projected from 2006 to 2013 using a 2.8\% growth rate estimate of the National Bureau of Statistics (NBS). Table 1 shows the base scenario results of the national costs of electrification in Nigeria based on the NP modelling analysis. 
Table 1 Cost estimates for rural electrification in Nigeria

\begin{tabular}{lllllll}
\hline & $\begin{array}{l}\text { Total number of } \\
\text { households } \\
\text { electrified }\end{array}$ & $\begin{array}{l}\text { Percentage of } \\
\text { households } \\
\text { electrified }\end{array}$ & $\begin{array}{l}\text { System total } \\
\text { initial cost } \\
\text { (million US\$) }\end{array}$ & $\begin{array}{l}\text { Initial cost per } \\
\text { household } \\
\text { (US\$) }\end{array}$ & $\begin{array}{l}\text { System total recurring } \\
\text { cost per year } \\
\text { (million US\$) }\end{array}$ & $\begin{array}{l}\text { Recurring cost } \\
\text { per household } \\
\text { (US\$) }\end{array}$ \\
\hline $\begin{array}{l}\text { Grid LV + transformer } \\
\text { Grid MV }\end{array}$ & $27,833,318$ & 98 & 23,041 & 828 & 8,742 & 101 \\
Grid total & & 1,991 & 72 & 8,843 & 4 \\
$\begin{array}{l}\text { Mini-grid } \\
\text { Off-grid }\end{array}$ & 645,644 & 2 & 25,032 & 899 & 162 & 318 \\
Grand total & - & 500 & 775 & & 252 \\
\hline
\end{tabular}

At the national level, an overall total cost of US\$34.539 billion is estimated for the initial and yearly recurring costs for the 17-year planning period. A total number of 28.5 million households are to be electrified by 2030, which translates to an estimated 125 million people. Currently, an estimated 73 million Nigerians lack access to electricity going by the NBS figures of 2013.

The results further show that $98 \%{ }^{\mathrm{h}}$ of the households currently without access are to be electrified via grid expansion, while the remaining $2 \%$ will be electrified through mini-grid technology. The average connection cost per household for grid technology is US\$899, while that of the mini-grid is US\$775. Recurring cost per household per year for grid technology households is US\$318, while that of mini-grid is US\$316.

The system total levelized cost for the grid and mini-grid technologies are estimated at US $\$ 0.30$ and US $\$ 0.47^{j}$ per $\mathrm{kWh}$, respectively, over the planning period. Total length of MV and LV lines proposed under the base scenario is $12,193,060 \mathrm{~m}(12,193 \mathrm{~km})$ and 711,954,700 $\mathrm{m}(711,954 \mathrm{~km})$, respectively. Nigeria currently has a total transmission line of $12,337 \mathrm{~km}$, which is, $5,650 \mathrm{~km}$ of $330 \mathrm{kV}$ transmission lines and 6,687 km of $132 \mathrm{kV}$ transmission lines. The implication of results from the analysis is that an additional $12,193 \mathrm{~km}$ of MV lines is required for $100 \%$ expansion of electricity to rural Nigeria. Unfortunately, data for the LV distribution lines in Nigeria is not available to researcher for comparison with the result derived from this research.

Overall, an average of US\$2 billion dollars annually is required for the next 17 years (2013 to 2030), in order to achieve $100 \%$ penetration rate of rural electrification in Nigeria. This will provide new access to electricity for an average of 1.68 million households yearly between the planning years (2013 to 2030).

In order to get a more disaggregated result, the same process applied to get the national level result was also applied to each of the 36 states of Nigeria and the capital city of Abuja. This entailed collating data for all the local government areas of all the states and running the model for each of the states in Nigeria. Table 2 shows the base scenario results of a more disaggregated electrification cost estimates for various states in Nigeria.
From Table 2, we observe that Kano state in the North-Western part of Nigeria and the most populous state in Nigeria according to the 2006 census have the highest number of households without electricity at 1.8 million people approximately. An average of 769,000 households in each state of the federation lack access to electricity, and the state with the least number of unelectrified households is Edo state at 106,000 households approximately.

As expected, the grid technology is the preferred and least-cost technology for rural electrification in most states, with most states going $100 \%$ grid, and averagely $95 \%$, while the state with the least grid penetration is Imo state in South-Eastern Nigeria, with a recommended grid penetration rate of $65 \%$. The mini-grid technology has an average of $2 \%$ in terms of households electrified, and Imo state again takes the lead as the state with the highest mini-grid recommended technology at $35 \%$.

We also observe that while Kano state has the highest number of unelectrified households, it is not necessarily the most costly state to electrify. Borno state is the most costly grid-based state to electrify in Nigeria with an approximate cost of US $\$ 2.9$ billion, while the least expensive grid-based state to electrify is Edo state at US\$73 million. An average cost of US $\$ 1$ billion dollars would be required to electrify each state in Nigeria. Reasons for this disparity in costs for grid based electrification for different regions can be attributed to distance of locations from existing grid infrastructure, topography and population size of different regions.

For mini-grid recommended households, Oyo state in South-West Nigeria will require an estimated US\$183 million being the highest for mini-grid component of its electrification, while an average of US\$35 million of mini-grid technology investment is required for electrification of various states in Nigeria, and Abia state in South-East Nigeria requires about US $\$ 6$ million for its mini-grid component of rural electrification.

Taraba state which is currently the least electrified state in Nigeria requires $96 \%$ grid extension and $4 \%$ mini-grid technology for rural electrification. This translates into US $\$ 1.18$ billion for grid expansion and US\$39.7 million cost 
Table 2 Cost estimates for rural electrification of various states in Nigeria

\begin{tabular}{|c|c|c|c|c|c|c|c|c|c|}
\hline & \multirow[t]{2}{*}{$\begin{array}{l}\text { Total number of } \\
\text { households } \\
\text { electrified }\end{array}$} & \multicolumn{2}{|c|}{$\begin{array}{l}\text { Percentage of } \\
\text { households } \\
\text { electrified }\end{array}$} & \multicolumn{3}{|c|}{ Cost of grid (US\$) } & \multicolumn{3}{|c|}{ Cost of mini-grid (US\$) } \\
\hline & & Grid & Mini-grid & $\begin{array}{l}\text { Total (million } \\
\text { US\$) }\end{array}$ & $\begin{array}{l}\text { Per } \\
\text { household }\end{array}$ & Levelized & $\begin{array}{l}\text { Total (million } \\
\text { US\$) }\end{array}$ & $\begin{array}{l}\text { Per } \\
\text { household }\end{array}$ & Levelized \\
\hline \multicolumn{10}{|l|}{ State } \\
\hline Abia & 411,623 & 98 & 2 & 439 & 1,084 & 0.38 & 6 & 995 & 0.50 \\
\hline Adamawa & $1,048,161$ & 98 & 2 & 1,349 & 1,288 & 0.29 & 18 & 1,047 & 0.46 \\
\hline Akwa-lbom & 972,903 & 100 & - & 1,047 & 1,077 & 0.35 & - & - & - \\
\hline Anambra & 295,991 & 90 & 10 & 2,743 & 1,030 & 0.41 & 29 & 1,006 & 0.49 \\
\hline Bauchi & 951,368 & 98 & 2 & 1,241 & 1,338 & 0.27 & 26 & 1,107 & 0.44 \\
\hline Bayelsa & 315,937 & 100 & - & 361 & 1,144 & 0.35 & - & - & - \\
\hline Benue & $1,198,680$ & 100 & - & 1,511 & 1,261 & 0.28 & - & - & - \\
\hline Borno & $1,589,400$ & 100 & - & 2,287 & 1,439 & 0.26 & - & - & - \\
\hline Cross river & 650,128 & 97 & 3 & 742 & 1,184 & 0.35 & 23 & 1,023 & 0.48 \\
\hline Delta & $1,145,787$ & 100 & - & 1,245 & 1,087 & 0.34 & - & - & - \\
\hline Ebonyi & 637,375 & 100 & - & 757 & 1,189 & 0.30 & - & - & - \\
\hline Edo & 106,335 & 69 & 31 & 72 & 991 & 0.42 & 32 & 991 & 0.50 \\
\hline Ekiti & 325,939 & 95 & 5 & 334 & 1,082 & 0.42 & 16 & 1,000 & 0.49 \\
\hline Enugu & 770,522 & 100 & - & 867 & 1,126 & 0.32 & - & - & - \\
\hline FCT-Abuja & 245,440 & 89 & 11 & 327 & 1,501 & 0.24 & 27 & 1,028 & 0.47 \\
\hline Gombe & 601,375 & 100 & - & 768 & 1,278 & 0.27 & - & - & - \\
\hline Imo & 195,075 & 65 & 35 & 132 & 1,035 & 0.43 & 67 & 997 & 0.49 \\
\hline Jigawa & $1,060,396$ & 100 & - & 1,336 & 1,261 & 0.29 & - & - & - \\
\hline Kaduna & $1,248,819$ & 100 & - & 1,598 & 1,280 & 0.27 & - & - & - \\
\hline Kano & $1,729,744$ & 100 & - & 2,147 & 1,241 & 0.28 & - & - & - \\
\hline Katsina & $1,405,492$ & 100 & - & 2,009 & 1,430 & 0.31 & - & - & - \\
\hline Kebbi & 750,452 & 97 & 3 & 874 & 1,200 & 0.32 & 22 & 1,068 & 0.45 \\
\hline Kogi & 756,733 & 92 & 8 & 806 & 1,158 & 0.36 & 62 & 1,037 & 0.47 \\
\hline Kwara & 323,549 & 76 & 24 & 259 & 1,056 & 0.38 & 80 & 1,031 & 0.47 \\
\hline Lagos & 343,028 & 96 & 4 & 327 & 997 & 0.38 & 14 & 994 & 0.50 \\
\hline Nasarawa & 457,742 & 96 & 4 & 532 & 1,211 & 0.33 & 18 & 1,038 & 0.47 \\
\hline Niger & $1,098,726$ & 100 & - & 1,303 & 1,186 & 0.30 & - & - & - \\
\hline Ogun & 515,463 & 94 & 6 & 505 & 1,041 & 0.37 & 30 & 1,000 & 0.49 \\
\hline Ondo & 828,557 & 100 & - & 902 & 1,089 & 0.35 & - & - & - \\
\hline Osun & 457,604 & 96 & 4 & 449 & 1,019 & 0.41 & 16 & 995 & 0.50 \\
\hline Oуо & 865,891 & 79 & 21 & 730 & 1,063 & 0.37 & 182 & 1,020 & 0.48 \\
\hline Plateau & 829,789 & 100 & - & 1,104 & 1,331 & 0.28 & - & - & - \\
\hline Rivers & 797,321 & 100 & - & 890 & 1,116 & 0.33 & - & - & - \\
\hline Sokoto & $1,026,713$ & 98 & 2 & 1,270 & 1,260 & 0.30 & 20 & 1,055 & 0.46 \\
\hline Taraba & 910,651 & 96 & 4 & 1,184 & 1,353 & 0.29 & 39 & 1,137 & 0.42 \\
\hline Yobe & 685,347 & 97 & 3 & 818 & 1,226 & 0.29 & 18 & 1,055 & 0.46 \\
\hline Zamfara & 907,400 & 100 & - & 1,235 & 1,361 & 0.27 & - & - & - \\
\hline High & $1,729,744$ & 100 & 35 & 2,287 & 1,501 & 0.43 & 182 & 1,137 & 0.50 \\
\hline Average & 769,229 & 95 & 2 & 920 & 1,190 & 0.33 & 35 & 1,031 & 0.47 \\
\hline Low & 106,335 & 65 & 9 & 72 & 991 & 0.24 & 6 & 991 & 0.42 \\
\hline
\end{tabular}


of mini-grid investment for rural electrification over the planning period.

The levelized costs of each system technology as well as costs per households are also shown in Table 2. We observe that the average levelized cost of grid-based electrification (US\$0.33) is lower than the mini-grid electrification of (US\$0.47). However, the cost per household of the mini-grid electrification option (US\$1,031) is lower than that of the grid (US\$1,190) on the average ${ }^{k}$.

With the aid of the pivot table tool of Microsoft Excel 2010, the demand assumptions were categorized into four household level population sizes. The household bins are defined as follows: 1) 1 to $10,000,2) 10,001$ to $25,000,3$ ) $25,001$ to $50,000,4) 50,001$ to 100,000 and 5) $>100,000$. Figure 1 shows the base scenario household count by bin categorization. We observe from the graph that mini-grid technology is only viable in areas with populations between 1 and 25,000 households. However, household bins of 25,001 and above are $100 \%$ grid recommended. This goes to show that grid technology makes more economic sense in areas of higher/dense population than in sparsely populated areas.

Table 3 shows the estimated grid extension for the proposed MV and LV lines needed to connect households in various states in Nigeria. For grid compatible LGAs, the total MV and LV lines required to connect about 27.8 million proposed grid compatible households currently without access to electricity in Nigeria are $12,341,906 \mathrm{~m}$ and $711,954,700 \mathrm{~m}$, respectively. Furthermore, Nigeria requires an average of $0.43 \mathrm{~m}$ of MV grid length and $25.01 \mathrm{~m}$ of LV grid length to connect various households in each LGA that are grid compatible.

A break-down of the total length of MV and LV gridlines proposed per state from Table 3 shows that Borno state has the highest proposed MV gridline of 883,698 m, while Kano state has the highest proposed LV gridline of $43,242,500 \mathrm{~m}$ and Nasarawa state has the highest proposed
MV gridline per household of $0.77 \mathrm{~m}$. The three states are in the Northern region of Nigeria. On the other hand, Edo state has the least proposed MV and LV gridlines of 26, $271 \mathrm{~m}$ and 2,657,925 m, respectively, while Lagos state has the least proposed MV line per household of $0.11 \mathrm{~m}$. Both states have the highest existing grid coverage in Nigeria which makes them require relatively short lengths of MV lines needed to connect households compared to the North, and Lagos especially is highly populated with a high population density. Both states are in the southern part of Nigeria.

\section{Sensitivity analysis}

A sensitivity analysis was carried out to determine how outcomes of the model may vary with changes in the different input parameters. A specific evaluation of how effects of changes in cost of solar panels, diesel fuel cost and household electricity demand affect the results of the model was done. Results of the sensitivity analysis show that outcomes are indeed sensitive to changes in the cost of solar panels, diesel fuel cost and households demand as discussed below.

\section{Effects of reduction in solar panels}

A reduction in the cost of solar panels from US $\$ 2,000$ / $\mathrm{kW}$ used in the base scenario to US $\$ 500 / \mathrm{kW}$ (assuming a drastic crash in the cost of solar panels based on the current decreasing market trend for solar panels) would make grid the least-cost option for about $66 \%$ of the population and off-grid the least-cost option for $34 \%$ of the population. Total cost (US\$34.3 billion) is slightly lower than the base scenario of US\$34.5 billion, levelized costs for grid and off-grid systems are US\$0.28 and US $\$ 0.35$, respectively. Table 4 shows that while the total length of proposed LV lines remains the same as in the base case, a proposed length of MV line if solar panel reduces to US\$500 is $7,176,921 \mathrm{~m}$. This is lower than the

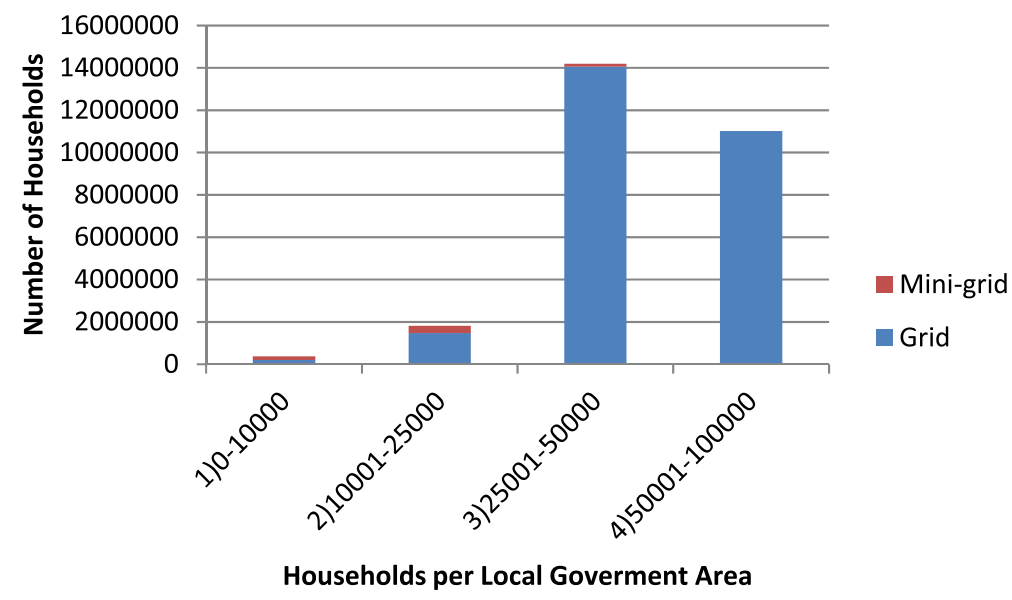

Figure 1 Base scenario household count by bin type'. 
Table 3 Proposed length of MV and LV lines for each state in Nigeria

\begin{tabular}{|c|c|c|c|c|c|}
\hline & \multirow{2}{*}{$\begin{array}{l}\text { Total number of } \\
\text { households electrified }\end{array}$} & \multicolumn{2}{|c|}{ Length of proposed MV lines } & \multicolumn{2}{|c|}{ Length of proposed LV lines } \\
\hline & & $\begin{array}{l}\text { Total (thousand } \\
\text { metres) }\end{array}$ & $\begin{array}{l}\text { Per household } \\
\text { (metres) }\end{array}$ & $\begin{array}{l}\text { Total (million } \\
\text { metres) }\end{array}$ & $\begin{array}{l}\text { Per household } \\
\text { (metres) }\end{array}$ \\
\hline \multicolumn{6}{|l|}{ State } \\
\hline Abia & 411,623 & 181 & 0.44 & 10 & 25.00 \\
\hline Adamawa & $1,048,161$ & 518 & 0.49 & 26 & 25.42 \\
\hline Akwa-lbom & 972,903 & 278 & 0.29 & 24 & 25.00 \\
\hline Anambra & 295,991 & 105 & 0.36 & 7 & 25.00 \\
\hline Bauchi & 951,368 & 508 & 0.53 & 23 & 25.00 \\
\hline Bayelsa & 315,937 & 161 & 0.51 & 7 & 25.00 \\
\hline Benue & $1,198,680$ & 548 & 0.46 & 29 & 25.00 \\
\hline Borno & $1,589,400$ & 883 & 0.56 & 39 & 25.00 \\
\hline Cross river & 650,128 & 445 & 0.69 & 16 & 25.00 \\
\hline Delta & $1,145,787$ & 325 & 0.28 & 28 & 25.00 \\
\hline Ebonyi & 637,375 & 194 & 0.31 & 15 & 25.00 \\
\hline Edo & 106,335 & 26 & 0.25 & 2 & 25.00 \\
\hline Ekiti & 325,939 & 190 & 0.58 & 8 & 25.00 \\
\hline Enugu & 770,522 & 209 & 0.27 & 19 & 25.00 \\
\hline FCT-Abuja & 245,440 & 77 & 0.32 & 6 & 25.00 \\
\hline Gombe & 601,375 & 184 & 0.31 & 15 & 25.00 \\
\hline Imo & 195,075 & 76 & 0.39 & 4 & 25.00 \\
\hline Jigawa & $1,060,396$ & 513 & 0.48 & 26 & 25.00 \\
\hline Kaduna & $1,248,819$ & 408 & 0.33 & 31 & 25.00 \\
\hline Kano & $1,729,744$ & 513 & 0.30 & 43 & 25.00 \\
\hline Katsina & $1,405,492$ & 595 & 0.42 & 35 & 25.00 \\
\hline Kebbi & 750,452 & 464 & 0.62 & 18 & 25.00 \\
\hline Kogi & 756,733 & 465 & 0.62 & 18 & 25.00 \\
\hline Kwara & 323,549 & 141 & 0.44 & 8 & 25.00 \\
\hline Lagos & 343,028 & 37 & 0.11 & 8 & 25.00 \\
\hline Nasarawa & 457,742 & 352 & 0.77 & 11 & 25.00 \\
\hline Niger & $1,098,726$ & 405 & 0.37 & 27 & 25.00 \\
\hline Ogun & 515,463 & 152 & 0.30 & 12 & 25.00 \\
\hline Ondo & 828,557 & 266 & 0.32 & 20 & 25.00 \\
\hline Osun & 457,604 & 168 & 0.37 & 11 & 25.00 \\
\hline Oyo & 865,891 & 292 & 0.34 & 21 & 25.00 \\
\hline Plateau & 829,789 & 394 & 0.48 & 20 & 25.00 \\
\hline Rivers & 797,321 & 258 & 0.32 & 19 & 25.00 \\
\hline Sokoto & $1,026,713$ & 585 & 0.57 & 25 & 25.00 \\
\hline Taraba & 910,651 & 683 & 0.75 & 22 & 25.00 \\
\hline Yobe & 685,347 & 295 & 0.43 & 17 & 25.00 \\
\hline Zamfara & 907,400 & 428 & 0.47 & 22 & 25.00 \\
\hline High & $1,729,744$ & 883 & 0.77 & 43 & 25.40 \\
\hline Average & 769,229 & 333 & 0.43 & 19 & 25.01 \\
\hline Low & 195,075 & 26 & 0.11 & 2 & 25.00 \\
\hline
\end{tabular}


Table 4 Cost summary table for solar panel reduction to $\$ \mathbf{5 0 0}$

\begin{tabular}{|c|c|c|c|c|c|c|c|c|c|}
\hline & $\begin{array}{l}\text { Total number } \\
\text { of households } \\
\text { electrified } \\
\text { (million) }\end{array}$ & $\begin{array}{l}\text { Percentage of } \\
\text { households } \\
\text { electrified }\end{array}$ & $\begin{array}{l}\text { System } \\
\text { total initial } \\
\text { cost (million } \\
\text { US\$) }\end{array}$ & $\begin{array}{l}\text { Initial cost } \\
\text { per } \\
\text { household } \\
\text { (US\$) }\end{array}$ & $\begin{array}{l}\text { System total } \\
\text { recurring cost } \\
\text { per year } \\
\text { (million US\$) }\end{array}$ & $\begin{array}{l}\text { Recurring } \\
\text { cost per } \\
\text { household } \\
\text { (US\$) }\end{array}$ & $\begin{array}{l}\text { Levelized } \\
\text { cost (US\$) }\end{array}$ & $\begin{array}{l}\text { Proposed } \\
\text { LV line } \\
\text { (million } \\
\text { metres) }\end{array}$ & $\begin{array}{l}\text { Proposed } \\
\text { MV line } \\
\text { (million } \\
\text { metres) }\end{array}$ \\
\hline $\begin{array}{l}\text { Grid LV + } \\
\text { transformer }\end{array}$ & & & 15,826 & 843 & 6,899 & 368 & & 711 & 7 \\
\hline Grid total & & 16,936 & 903 & 6,959 & 371 & 0.28 & & & \\
\hline \multicolumn{10}{|l|}{ Mini-grid } \\
\hline Off-grid & 9 & 34 & 8,833 & 909 & 1,603 & 165 & 0.35 & & \\
\hline Grand total & 28 & & 25,769 & 905 & 8,562 & 301 & & & \\
\hline
\end{tabular}

base scenario length of 12,193,060 m, due to more LGAs becoming off-grid compatible.

Figure 2 shows the household count by bin type. We observe that for LGAs with households ranging from 1 to 10,000 , off-grid technology was recommended as the leastcost option, same for LGAs with population ranging from 10,001 to 25,000 , and a part of LGAs with a population range of 25,001 to 50,000 and 50,001 to 100,000 . However, LGAs with population of 100,000 and above all went for grid as the least-cost option. This scenario is slightly different from the base scenario where populations from 50,001 and above all went for grid as the least-cost option.

Figure 3 shows the map of Nigeria with the recommended technologies in various states in Nigeria when the cost of solar panels reduces from US $\$ 2,000 / \mathrm{kW}$ to US $\$ 500 / \mathrm{kW}$. It was drawn with the aid of the ArcGIS software 2010 [16].

\section{Effects of changes in diesel fuel cost}

Reducing the pump price of diesel fuel from US $\$ 0.96$ to US $\$ 0.65$ in this scenario based on projected improvement in diesel refining capacity in Nigeria and diesel availability at competitive market price when Dangote Group's 400,000 barrels a day refining capacity eventually comes up in 2016, results in a significant shift in the population covered by the diesel mini-grid system. Table 5 shows that for other variables remaining equal, the grid compatible population reduces from $98 \%$ in the base scenario to $51 \%$ when diesel price alone is reduced to US $\$ 0.65$, while the minigrid population increases to $49 \%$ from $2 \%$ in the base scenario. This is due to affordability of the mini-grid system as diesel price which is a major input is reduced drastically, as more LGAs are now able to afford it.

We also observe a reduction in MV line length to $3,450,760 \mathrm{~m}$ compared to the base scenario, as well as a lower levelized cost and total initial cost. However, the total recurring cost in this scenario is higher than the base scenario; this may not be unconnected with the purchase of diesel on a regular basis for the mini-grid system.

We observe from Figure 4 that more household bins (0 to $100,000)$ now use the mini-grid system, as opposed to the base scenario where only household bins from 0 to 25,000 only used mini-grid. It goes to show that affordability of any technology is a major factor in determining the number of households that will embrace a rural electrification technology option.

Figure 5 shows the map of Nigeria and recommended technologies when diesel price is reduced. We observe that the red and black dots are now almost evenly spread around the country when compared to the base scenario that had the red dots spread almost in all parts of the country.

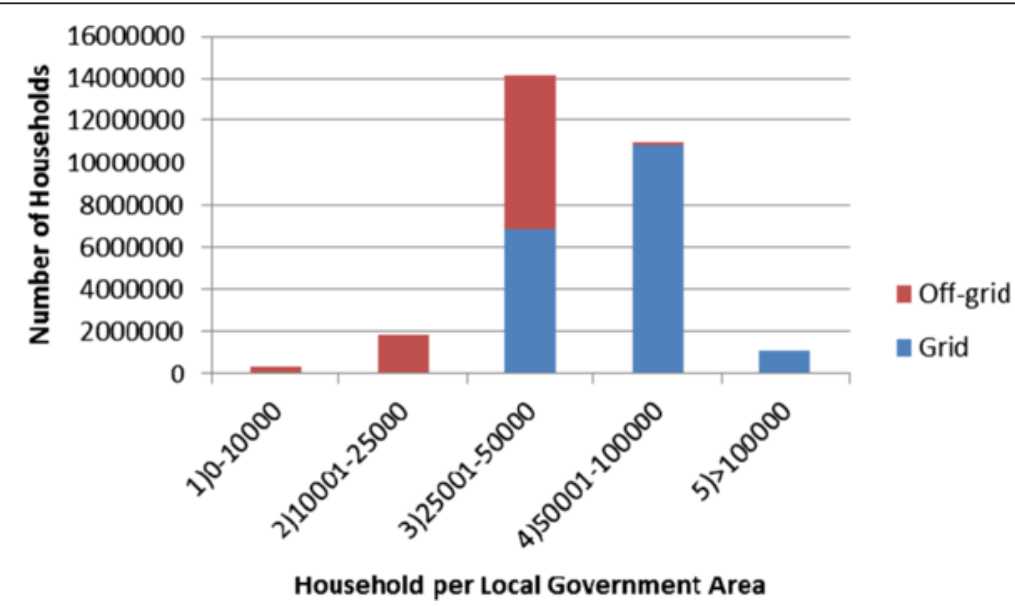

Figure 2 Household count by bin type (solar panel US\$500). 


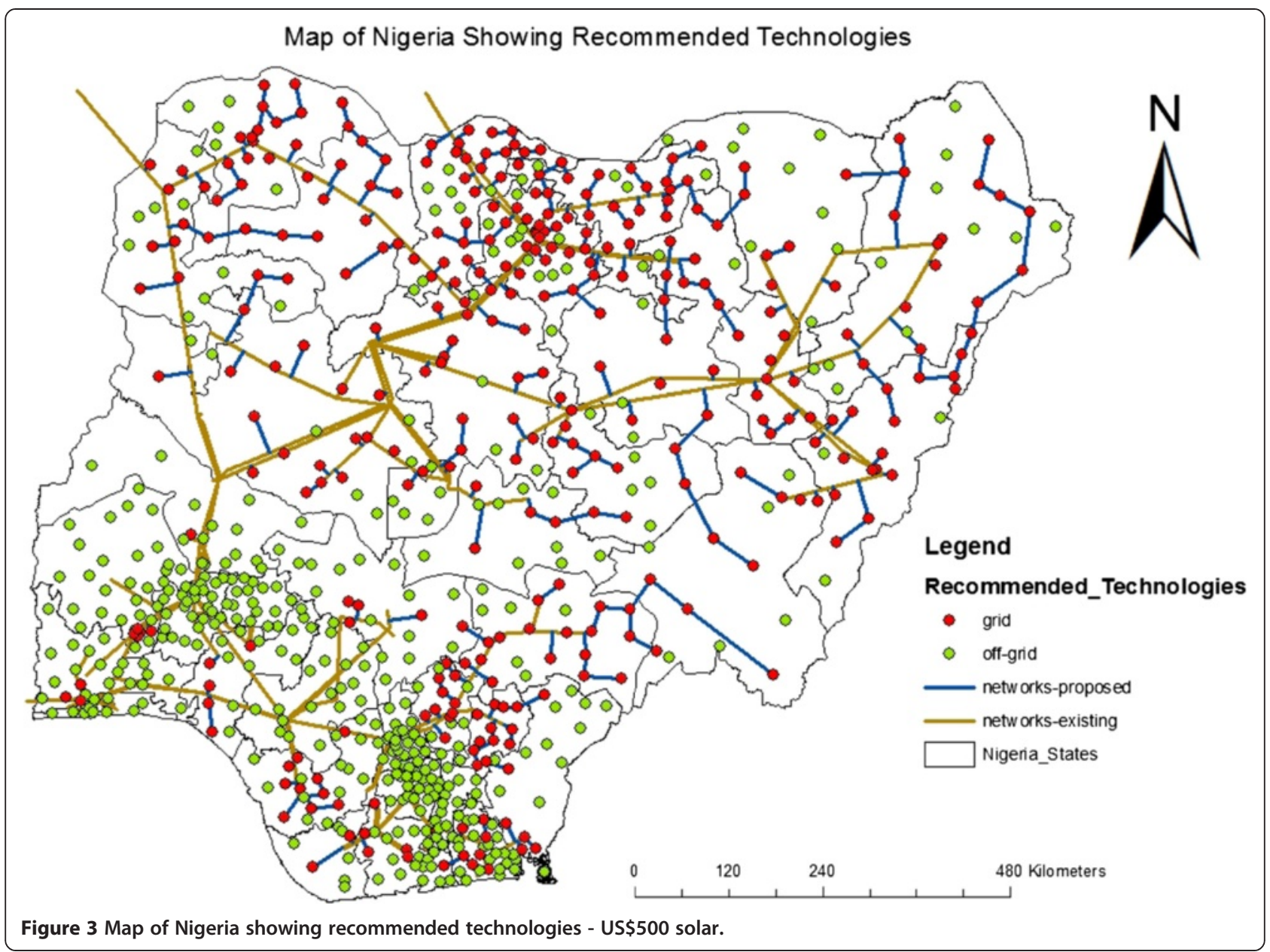

Effects of simultaneous change in solar panels and diesel fuel

From the preceding scenarios, we have seen the effect of a reduction in solar panels alone as well as a reduction in diesel fuel price alone. In this scenario, a simultaneous reduction in solar panels to US\$500 and diesel fuel price to US $\$ 0.65$ results in a fairly balanced allocation of population for each technology option. Under this scenario, $46 \%$ of the population would be supplied by the grid as the leastcost option, $24 \%$ of the population would be served via mini-grid as the least-cost option, while $30 \%$ would be served with off-grid technology option as the least cost.

Table 6 shows that the levelized costs for grid and mini-grid are also lower compared to the base scenario, as well as the system total initial cost and recurring cost. The table also shows that while total proposed LV line

Table 5 Cost summary table for reduction of diesel cost to $\mathbf{\$ 0 . 6 5}$

\begin{tabular}{|c|c|c|c|c|c|c|c|c|c|}
\hline & $\begin{array}{l}\text { Total number } \\
\text { of households } \\
\text { electrified } \\
\text { (million) }\end{array}$ & $\begin{array}{l}\text { Percentage of } \\
\text { households } \\
\text { electrified }\end{array}$ & $\begin{array}{l}\text { System } \\
\text { total initial } \\
\text { cost (million } \\
\text { US\$) }\end{array}$ & $\begin{array}{l}\text { Initial cost per } \\
\text { household } \\
\text { (dollars) }\end{array}$ & $\begin{array}{l}\text { System total } \\
\text { recurring cost } \\
\text { per year (million } \\
\text { US\$) }\end{array}$ & $\begin{array}{l}\text { Recurring } \\
\text { cost per } \\
\text { household } \\
\text { (US\$) }\end{array}$ & $\begin{array}{l}\text { Levelized } \\
\text { cost } \\
\text { (US\$) }\end{array}$ & $\begin{array}{l}\text { Proposed } \\
\text { LV line } \\
\text { (million } \\
\text { metres) }\end{array}$ & $\begin{array}{l}\text { Proposed } \\
\text { MV line } \\
\text { (million } \\
\text { metres) }\end{array}$ \\
\hline $\begin{array}{l}\text { Grid LV+ } \\
\text { transformer }\end{array}$ & & & 12,385 & 845 & 5,458 & 372 & & 711 & 3 \\
\hline Grid total & & & 12,838 & 876 & 9,246 & 631 & 0.28 & & \\
\hline Mini-grid & 13 & 49 & 11,354 & 822 & 3,565 & 258 & 0.34 & & \\
\hline Off-grid & - & & & & & & & & \\
\hline Grand total & 28 & 100 & 24,192 & 850 & 12,811 & 450 & & & \\
\hline
\end{tabular}




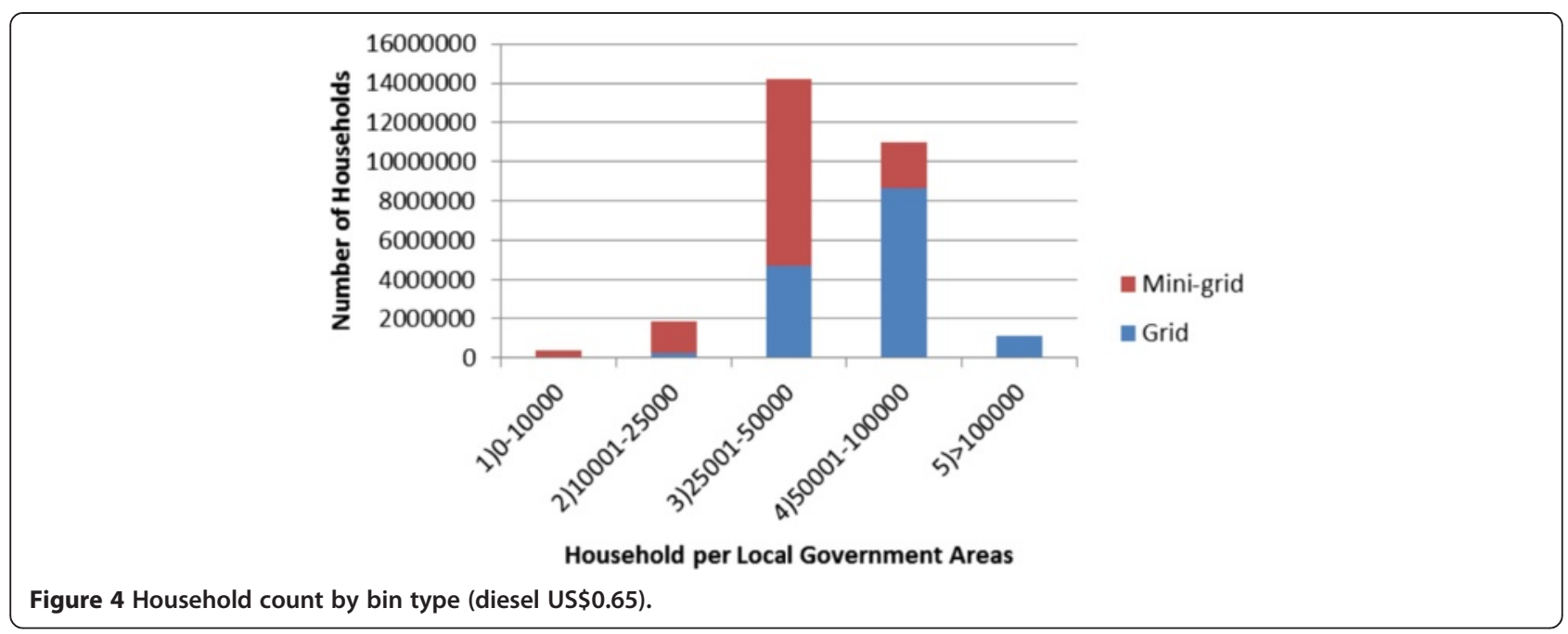

length remained unchanged, the total proposed MV line length in this scenario is significantly lower than the base scenario from 12,193,060 $\mathrm{m}$ to 3,271,686 $\mathrm{m}$.

Figure 6 depicts this scenario in a graph. The picture shows a diversified electrification technology base where the lower household bins range of 0 to 25,000 is wholly off-grid, LGAs with population of 25,001 to 50,000 are fairly diversified in terms of technology choice (off-grid, grid and mini-grid), and the upper households have more of grid and mini-grid.

The map of Nigeria in Figure 7 shows the recommended technologies by regions. The off-grid LGAs as seen in the map are more concentrated in the South-West and SouthSouth of the country, while the mini-grid option is more

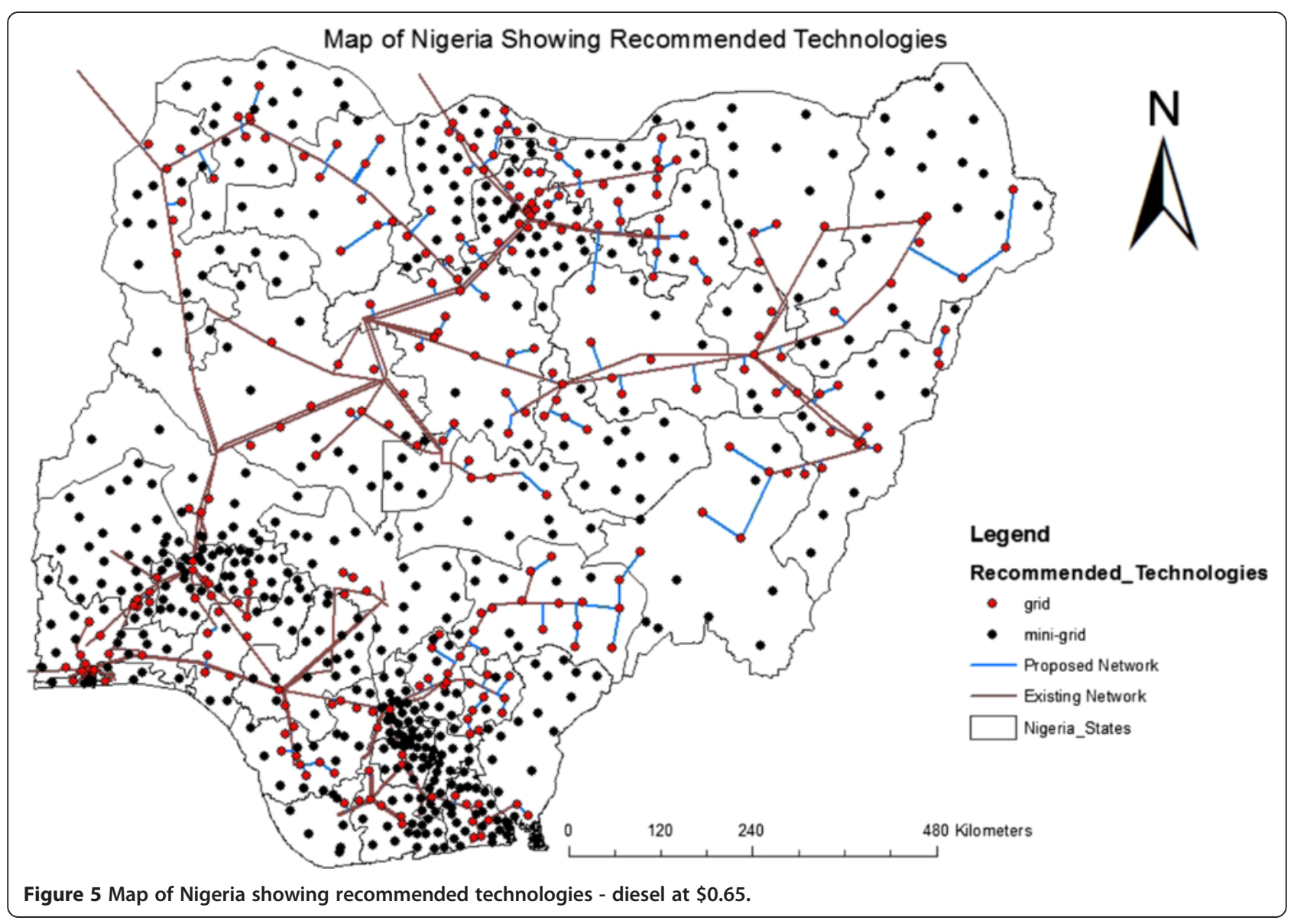


Table 6 Cost summary table for reducing solar panel cost to $\$ 500$ and diesel fuel cost to $\$ 0.65$

\begin{tabular}{|c|c|c|c|c|c|c|c|c|c|}
\hline & $\begin{array}{l}\text { Total number } \\
\text { of households } \\
\text { electrified } \\
\text { (million) }\end{array}$ & $\begin{array}{l}\text { Percentage of } \\
\text { households } \\
\text { electrified }\end{array}$ & $\begin{array}{l}\text { System } \\
\text { total initial } \\
\text { cost (million } \\
\text { US\$) }\end{array}$ & $\begin{array}{l}\text { Initial cost per } \\
\text { household } \\
\text { (dollars) }\end{array}$ & $\begin{array}{l}\text { System total } \\
\text { recurring cost } \\
\text { per year } \\
\text { (million US\$) }\end{array}$ & $\begin{array}{l}\text { Recurring } \\
\text { cost per } \\
\text { household } \\
\text { (US\$) }\end{array}$ & $\begin{array}{l}\text { Levelized } \\
\text { cost } \\
\text { (US\$) }\end{array}$ & $\begin{array}{l}\text { Proposed } \\
\text { LV line } \\
\text { (million } \\
\text { metres) }\end{array}$ & $\begin{array}{l}\text { Proposed } \\
\text { MV line } \\
\text { (million } \\
\text { metres) }\end{array}$ \\
\hline $\begin{array}{l}\text { Grid LV+ } \\
\text { transformer }\end{array}$ & & & 11,112 & 851 & 5,133 & 393 & & 711 & 3 \\
\hline Grid MV & 13 & 46 & 435 & 33 & 27 & 2 & & & \\
\hline Grid total & & & 11,548 & 884 & 5,161 & 395 & 0.27 & & \\
\hline Mini-grid & 7 & 24 & 5,965 & 857 & 2,177 & 313 & 0.31 & & \\
\hline Off-grid & 8 & 30 & 7,405 & 876 & 1,312 & 155 & 0.35 & & \\
\hline Grand total & 28 & 100 & 24,919 & 875 & 8,651 & 304 & & & \\
\hline
\end{tabular}

cost effective in the North-West and North-East. The grid system is spread all over the country but with particular presence in the North.

\section{Effects of changes in household demand}

An increase in demand from $330 \mathrm{kWh}$ in the base scenario to $400 \mathrm{kWh}$ makes the grid system the least-cost option for about $99 \%$ of the population, with the remaining $1 \%$ going for diesel mini-grid. Under this scenario, there is no off-grid recommended option due to the increase in household electricity demand. The grid system seems to be more viable for communities with high demand and population compared to sparsely populated areas which traditionally are off-grid compatible.

When household demand increases to $400 \mathrm{kWh}$, total MV line length increases from $12,193,060 \mathrm{~m}$ to $12,662,177 \mathrm{~m}$. The increase is attributed to connection of more LGAs to the grid as compared to the base scenario. On the whole, we observe that while an increase in demand leads to the connection of more LGAs and promotes access, it also increases initial and recurring costs, though not proportionate when compared to the base scenario. Table 7 gives more details.
Figure 8 shows that when demand increases, more households become grid compatible, even households between 0 and 10,000 that all went mini-grid or off-grid in other scenarios.

Figure 9 depicts this scenario in Nigeria's map. The red dots represent the grid LGAs while the black ones denote the mini-grid LGAs.

On the other hand, when electricity demand reduces from $330 \mathrm{kWh}$ in the base scenario to $250 \mathrm{kwh}$ in this scenario, naturally, less LGAs become grid compatible as observed in the decrease from $98 \%$ in the base scenario to $95 \%$ in this scenario. Table 8 shows that costs are reduced under this scenario, as well as MV line length. However, the levelized costs under this scenario are higher as seen in Table 8.

Figure 10 shows the map of Nigeria and recommended technologies when demand is reduced from $330 \mathrm{kWh}$ to $250 \mathrm{kWh}$.

\section{Comparison of results with other studies}

Table 9 uses the household as the unit of comparison between the results of our base scenario and case studies of Ghana [17,18], Senegal $[19,20]$ and Kenya [10]. Summary of results from the table reveals that while an estimated 28.5 million households will be electrified in

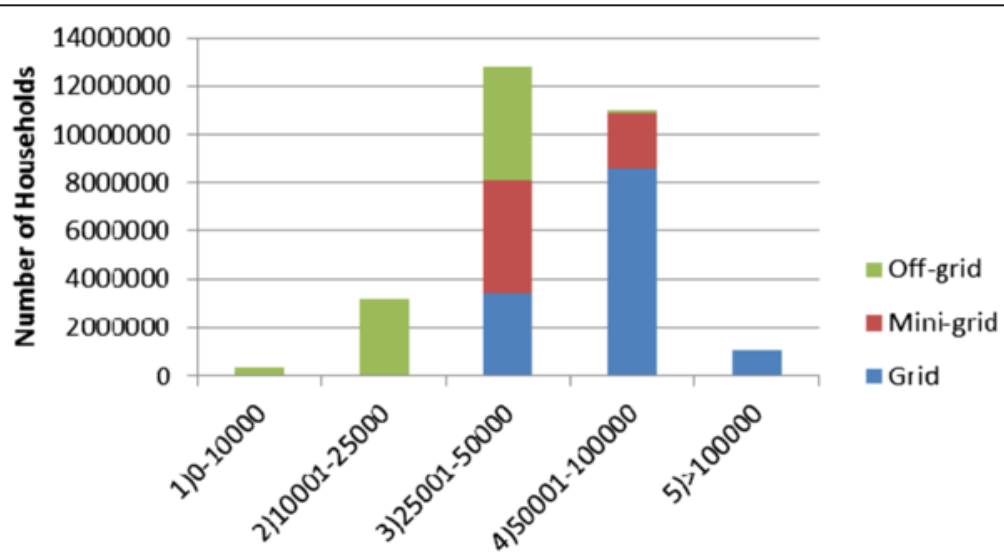

Households Per Local Government Area

Figure 6 Household count by bin type (solar US\$500 and diesel $\$ 0.65$ ). 


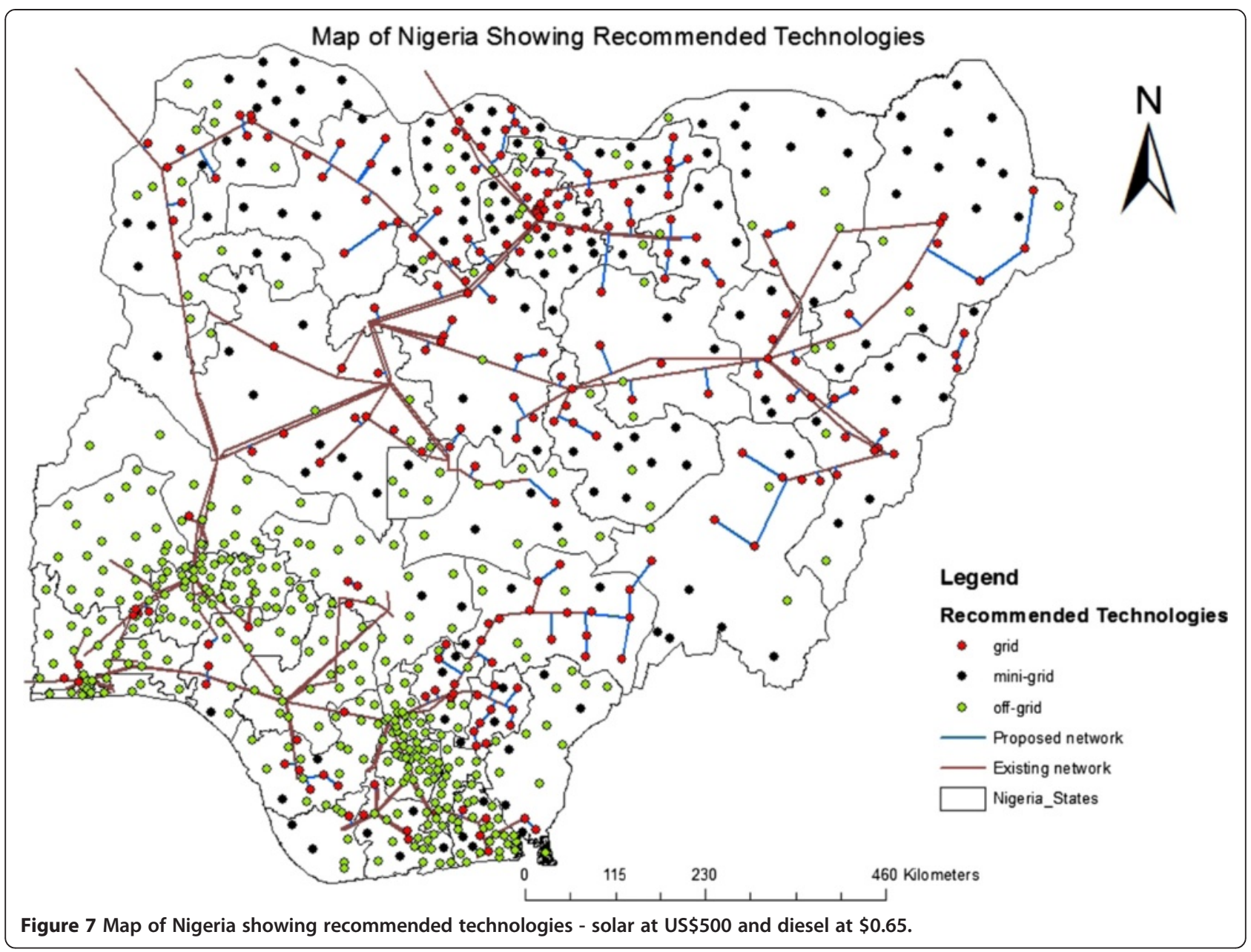

Nigeria, representing the highest, the average number of households electrified from the table is 9.4 million, while Senegal has the least number of 134,500 households electrified.

Average total electrification cost for the four countries compared is US $\$ 12.2$ billion, while the least was US $\$ 150$ million for Senegal. The variance in costs is attributed to the different time horizons used for various studies, as well as differences in population, household numbers, costs of various technology components and cost of diesel fuel.

However, in terms of per household costs, Ghana takes the lead with US\$2,082, followed by Kenya at US\$1,552, Nigeria with US\$1,212 and the lowest being Senegal at

Table 7 Cost summary table when demand increases to $400 \mathrm{kWh}$

\begin{tabular}{|c|c|c|c|c|c|c|c|c|c|}
\hline & $\begin{array}{l}\text { Total number of } \\
\text { households } \\
\text { electrified } \\
\text { (thousand) }\end{array}$ & $\begin{array}{l}\text { Percentage of } \\
\text { households } \\
\text { electrified }\end{array}$ & $\begin{array}{l}\text { System } \\
\text { total initial } \\
\text { cost (million } \\
\text { US\$) }\end{array}$ & $\begin{array}{l}\text { Initial cost per } \\
\text { household } \\
\text { (US\$) }\end{array}$ & $\begin{array}{l}\text { System total } \\
\text { recurring cost } \\
\text { per year } \\
\text { (million US\$) }\end{array}$ & $\begin{array}{l}\text { Recurring } \\
\text { cost per } \\
\text { household } \\
\text { (US\$) }\end{array}$ & $\begin{array}{l}\text { Levelized } \\
\text { costs } \\
\text { (US\$) }\end{array}$ & $\begin{array}{l}\text { Proposed } \\
\text { LV line } \\
\text { (million } \\
\text { metres) }\end{array}$ & $\begin{array}{l}\text { Proposed } \\
\text { MV line } \\
\text { (million } \\
\text { metres) }\end{array}$ \\
\hline $\begin{array}{l}\text { Grid LV+ } \\
\text { transformer }\end{array}$ & & & 23,776 & 844 & 10,408 & 369 & & 711 & 12 \\
\hline Grid MV & 28,173 & 99 & 2,083 & 74 & 105 & 4 & & & \\
\hline Grid total & & & 25,859 & 918 & 10,514 & 373 & 0.28 & & \\
\hline Mini-grid & 305 & 1 & 241 & 790 & 87 & 286 & 0.45 & & \\
\hline \multicolumn{10}{|l|}{ Off-grid } \\
\hline Grand total & 28,478 & 100 & 26,101 & 917 & 10,602 & 372 & & & \\
\hline
\end{tabular}




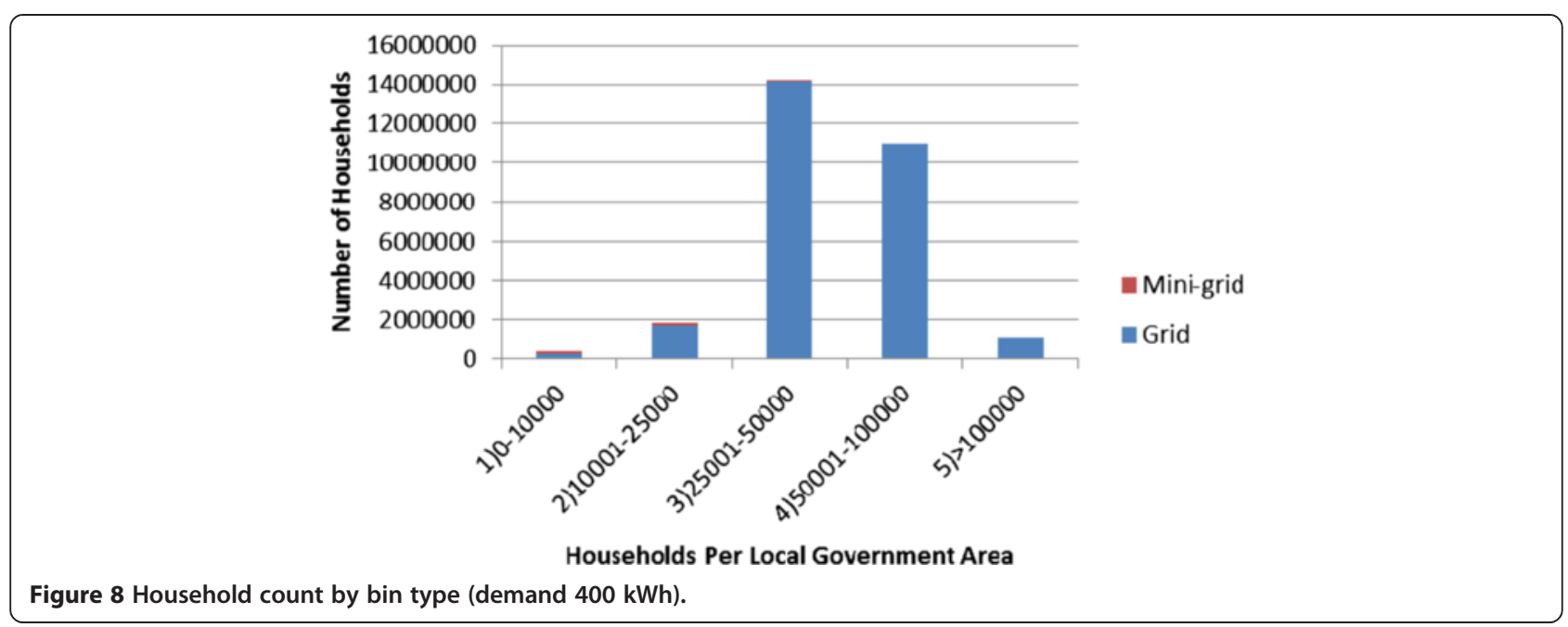

US\$1,048. Several factors such as population and number of households may be reasons attributable for the discrepancies.

For total length of proposed MV and LV lines, the table also reveals that Nigeria requires the highest, while Senegal requires the least. Although the per household costs vary, as more lengths of MV lines are required for
Senegal and Ghana when compared with Nigeria, while an average of $24 \mathrm{~m}$ of LV line length is required for all the countries compared.

\section{Conclusions}

The Network Planner (NP) model applied in this research is useful in electricity planning by decision

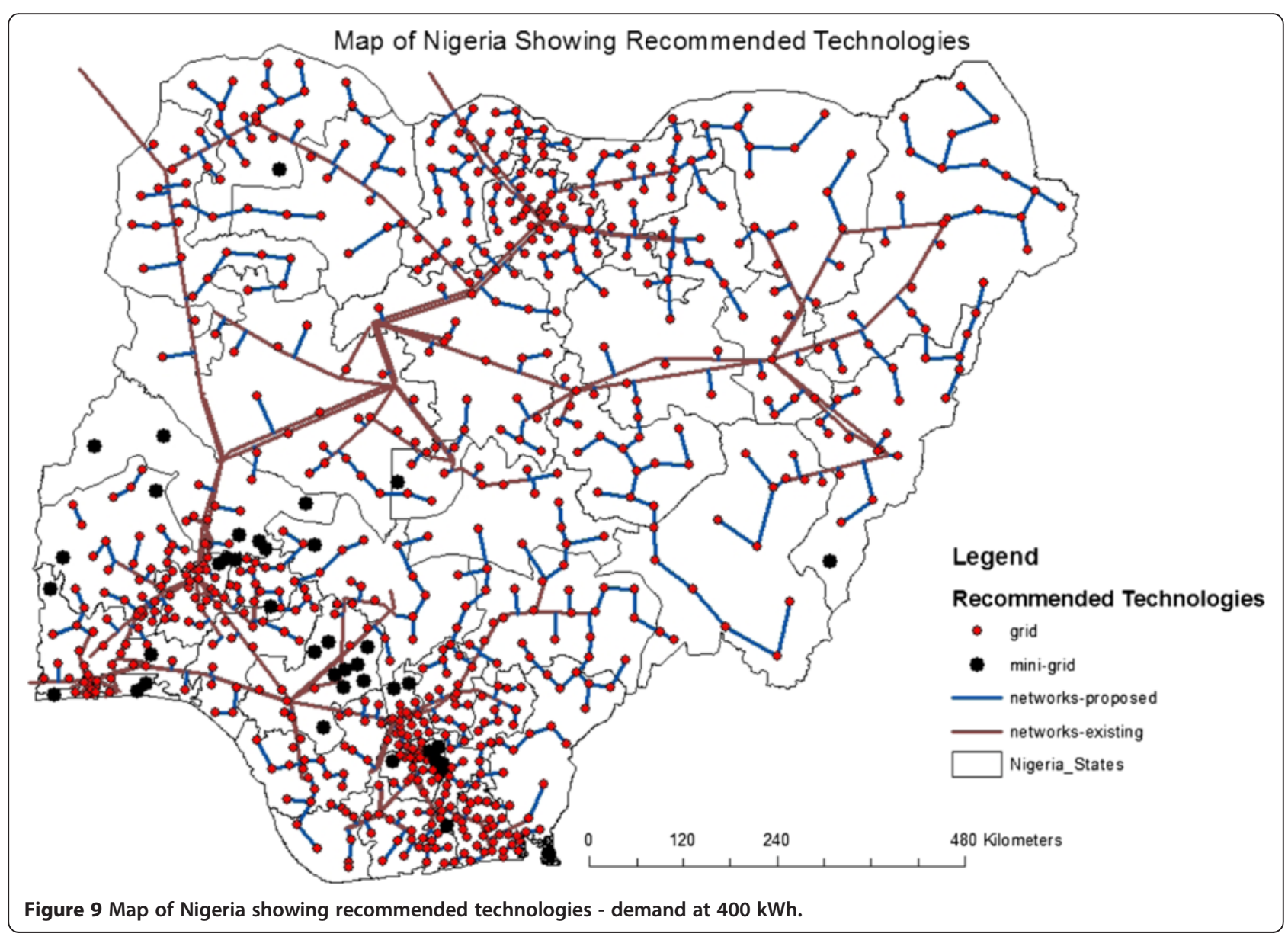


Table 8 Cost summary table when demand reduces to $250 \mathrm{kWh}$

\begin{tabular}{|c|c|c|c|c|c|c|c|c|c|}
\hline & $\begin{array}{l}\text { Total number of } \\
\text { households } \\
\text { electrified } \\
\text { (million) }\end{array}$ & $\begin{array}{l}\text { Percentage of } \\
\text { households } \\
\text { electrified }\end{array}$ & $\begin{array}{l}\text { System total } \\
\text { initial cost } \\
\text { (million } \\
\text { US\$) }\end{array}$ & $\begin{array}{l}\text { Initial } \\
\text { cost per } \\
\text { household }\end{array}$ & $\begin{array}{l}\text { System total } \\
\text { recurring cost } \\
\text { per year } \\
\text { (million US\$) }\end{array}$ & $\begin{array}{l}\text { Recurring } \\
\text { cost per } \\
\text { household }\end{array}$ & $\begin{array}{l}\text { Levelized } \\
\text { cost }\end{array}$ & $\begin{array}{l}\text { Proposed } \\
\text { LV line } \\
\text { (million } \\
\text { metres) }\end{array}$ & $\begin{array}{l}\text { Proposed } \\
\text { MV line } \\
\text { (million } \\
\text { metres) }\end{array}$ \\
\hline $\begin{array}{l}\text { Grid LV + } \\
\text { transformer }\end{array}$ & & & 21,866 & 810 & 6,790 & 251 & & 711 & 11 \\
\hline Grid MV & 27 & 95 & 1,808 & 67 & 93 & 3 & & & \\
\hline Grid total & & & 23,674 & 877 & 6,883 & 255 & 0.33 & & \\
\hline Mini-grid & 1 & 5 & 1,114 & 758 & 312 & 213 & 0.52 & & \\
\hline \multicolumn{10}{|l|}{ Off-grid } \\
\hline Grand total & 28 & 100 & 24,789 & 870 & 7,196 & 253 & & & \\
\hline
\end{tabular}

makers, especially in the area of investment cost estimates and least-cost technology options required for electrification purposes in Nigeria. Through a blend of demographic data, geographical information, current diesel prices, costs of solar components and so on, it becomes possible to estimate and map the economic potential of different technology options for rural electrification in Nigeria. More so, within a specific planning period, planners can determine with the aid of this model, communities that would become grid, off-grid or mini-grid compatible, either at local or national levels based on available data.

Results from this research shows that by the end of the 17-year planning period (2013 to 2030), 98\% of currently un-electrified communities will be viable for grid expansion, while only $2 \%$ will be mini-grid compatible. This is based on a proposed MV line extension of $12,193,060 \mathrm{~m}$, LV line length proposal of 711,954,700 m

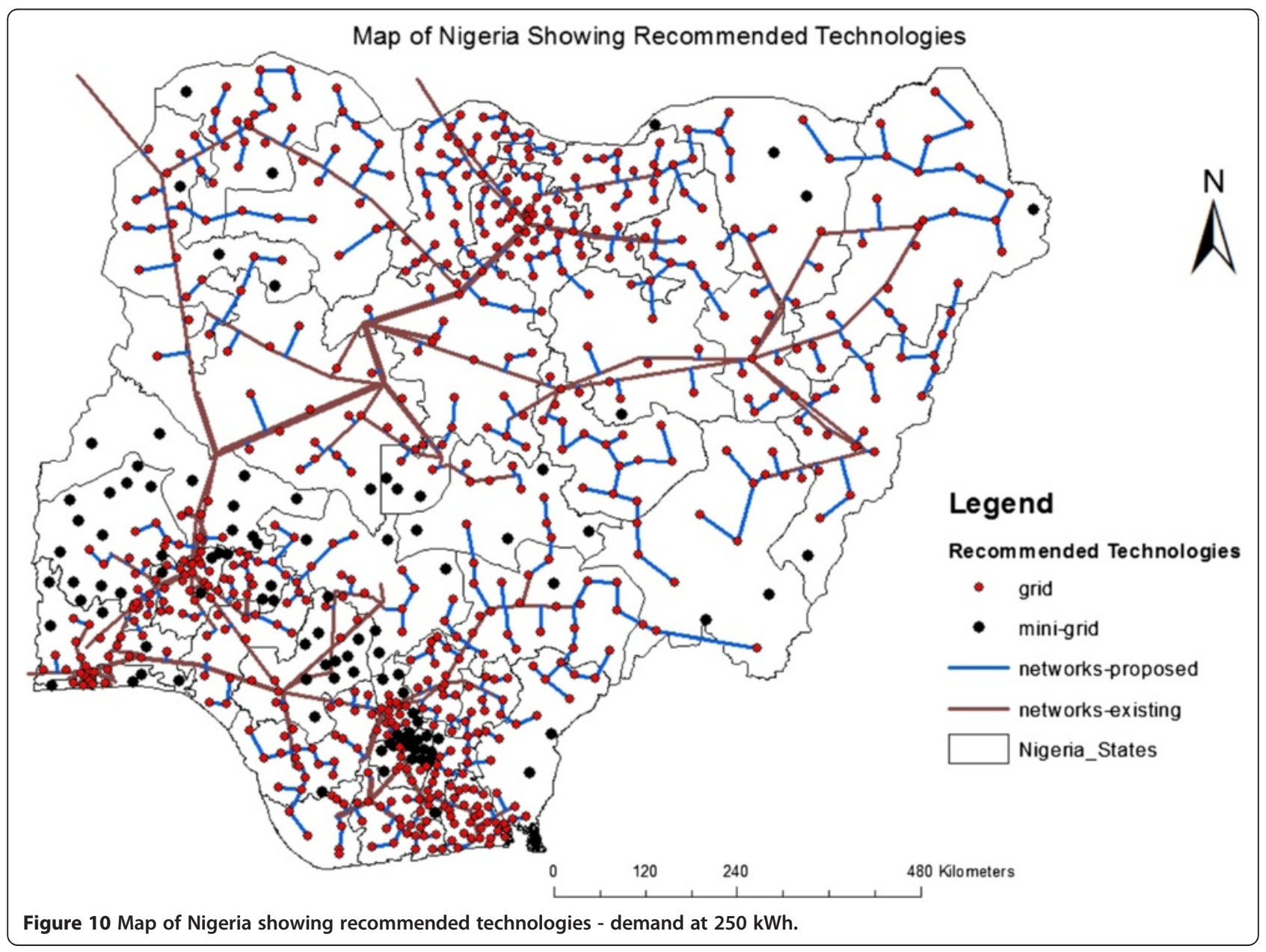


Table 9 Base scenario result comparison with other studies

\begin{tabular}{|c|c|c|c|c|c|c|}
\hline \multirow[t]{2}{*}{ Country } & \multirow{2}{*}{$\begin{array}{l}\text { Total number of } \\
\text { households } \\
\text { electrified }\end{array}$} & \multirow{2}{*}{$\begin{array}{l}\text { Costs of electrification } \\
\text { Per household } \\
\text { (US\$) }\end{array}$} & \multicolumn{2}{|c|}{ Length of proposed MV lines } & \multicolumn{2}{|c|}{ Length of proposed LV lines } \\
\hline & & & $\begin{array}{l}\text { Total (million } \\
\text { metres) }\end{array}$ & $\begin{array}{l}\text { Per household } \\
\text { (metres) }\end{array}$ & $\begin{array}{l}\text { Total (million } \\
\text { metres) }\end{array}$ & $\begin{array}{l}\text { Per household } \\
\text { (metres) }\end{array}$ \\
\hline Nigeria & $28,478,962$ & 1,212 & 12 & 0.4 & 712 & 25.0 \\
\hline Ghana & 284,147 & 2,082 & 7 & 26.2 & 7 & 24.4 \\
\hline Senegal & 134,448 & 1,048 & 3 & 27.5 & 3 & 24.0 \\
\hline Kenya & $8,700,000$ & 1,552 & - & - & - & - \\
\hline
\end{tabular}

and an estimated total cost of US\$34.6 billion investment within the planning period. An estimated 28.5 million households or an equivalent of 125 million people are projected to be provided electricity access by the end of the planning period in 2030. The off-grid technology seems to be unviable given the base scenario parameters and time horizon. It is worthy to note that the projections provided here are based on the best available input datasets, growth projections and demand estimates obtainable in Nigeria.

Sensitivity analysis carried out shows that the different input variables have various levels of influence on the total cost and technology options. For instance, a decrease in the cost of solar makes more communities to swing to off-grid compatibility even though the base scenario does not favour an off-grid technology option.

It is also noted that reducing household demand though reduces the overall cost of electrification but does not have too much effect on the number of households that become mini-grid compatible when compared to the drastic influence of other scenarios.

This spatial electricity planning effort using the Network Planner for Nigeria's case is the first attempt in Nigeria to highlight the importance of planning and data management in any electricity access reform. The study suggests how to proceed with rural electrification in Nigeria - to extend the grid or rely on local systems. Despite the model limitations, an attempt is made here to identify such choices at the local government level, which in itself is a very detailed work.

Any serious planning work requires better data, which is not available at present. Greater attention is required to collect and generate relevant information at a disaggregated ward/village levels in Nigeria.

\section{Policy implications}

- Implications for policymakers

- The off-grid technology was not recommended in this study due to its unviability. There is need for policymakers in the country to develop innovative ways of incentivising investments in rural off-grid renewable electricity generation projects.

- Implications for NREA

- This study provides the foundation for the NREA to develop a master-plan

- There is need for NREA to generate a database through direct surveys to get the real picture of rural electrification in Nigeria by collaborating with other agencies such as the National Bureau of Statistics, National Population Commission and Independent National Electoral Commission

- Solar should be promoted and integrated into the electrification programme of NREA

- Electrification projects should be prioritized according to the level of access in each state.

- Implications for the Federal Government of Nigeria (FGN).

- There is the need for the FGN to take the lead in the rural electrification drive of the nation.

- Funds need to be mobilized from various sources for grid expansion and electricity generation.

- The creation of an Energy Access Database or Data Management System for electricity network expansion is crucial.

- Corruption needs to be curbed within the sector.

In conclusion, further research should explore the use of other cheap fuel sources (wind, gas, hydro, etc.) based on availability and comparative advantage. This could have a great impact on costs. Micro-solar for households and finding solutions to sustainable biomass use could also be effectively pursued to bridge the energy access gap in Nigeria. Primary data based on actual household surveys at village and community levels would present more reliable results for electricity planning in Nigeria.

\section{Endnotes}

${ }^{\text {a}}$ This value is much lower than the IEA value earlier provided for the rural-urban shares. The discrepancy in values may be attributed to a number of factors such as sampling variability, incomplete coverage, reporting errors for individual units, non-response and imputations 
usually associated with surveys and data collection. However, the IEA data seems to be closer to the reality in Nigeria, and the idea is to provide a picture of the lack of electricity access situation in Nigeria, which can be deduced to be enormous from both sources (NBS and IEA).

${ }^{\mathrm{b}}$ Network Planner Version 0.9.7a, created by Sustainable Engineering Lab. Earth Institute, Columbia University, New York. http://networkplanner.modilabs.org/docs/ Accessed 14 January 2015.

${ }^{\mathrm{c}}$ The local government area (LGA), which is the lowest tier of government in Nigeria represents a demand node herein. Nigeria has 774 LGAs in 36 states and the capital city of Abuja.

${ }^{\mathrm{d}}$ Nigeria uses $16 \mathrm{kV}$ and $33 \mathrm{kV}$ lines for power distribution, as well as $132 \mathrm{kV}$ and $330 \mathrm{kV}$ high voltage (HV) lines for power transmission. The NP model uses LV and medium voltage as the default lines for analysis. However, the MV lines used in this research include the cost of connecting $16 \mathrm{kV}, 33 \mathrm{kV}, 132 \mathrm{kV}$ and $330 \mathrm{kV}$ in line with what is obtainable in Nigeria. Therefore, the $\mathrm{HV}$ lines are incorporated in the NP model as MV lines for ease of representation and conformity with the model.

${ }^{\mathrm{e}}$ Ibid note 3.

${ }^{f}$ In line with IEA Energy Outlook 2011, towards providing energy for all in 2030, 2013 to 2030 (17 years) was adopted as time horizon for this study.

${ }^{\text {g}}$ Sources for technology costs data includes Nigeria's Ministry of Power, Energy Commission of Nigeria, System Operator, distribution companies in Nigeria, National pump price for diesel and private solar PV dealers.

${ }^{h}$ This figure is high because of the large rural population of each of the 774 local government areas used for this analysis. This LGA level is the lowest unit of administration in Nigeria and data below this level is unavailable.

${ }^{\mathrm{i}}$ The NP model selects the least-cost supply option based on data for specific locations, population size, economy, costs of technologies, etc. Thus, if mini-grid is selected for a particular demand node, which means it is the cheapest to use there, same for grid and off-grid choices. Further, the results show that $98 \%$ of households in different locations in Nigeria are grid-compatible, while the remaining $2 \%$ are mini-grid compatible, and goes to show the total, average and recurring costs at such levels. Whichever location is selected as mini-grid for instance, then the grid and off-grid costs are definitely higher in such locations, and vice versa.

${ }^{\mathrm{j}}$ The levelized costs for the grid and mini-grid are large because of the 17-year planning period used in the modelling. An increase in the planning period from 17 to 30 years to allow more time for cost recovery, thus, reduces the levelized cost for grid supply to $\$ 0.20 / \mathrm{kWh}$, and mini-grid to $\$ 0.33 / \mathrm{kWh}$. The $\$ 0.14$ used as the electricity cost per $\mathrm{kWh}$ was used to capture costs of generation, transmission and distribution of power to various parts of Nigeria.

kibid note 8.

${ }^{\mathrm{I}}$ The large bin sizes as used here represent the large rural population data available at the disaggregated level of local government areas in Nigeria.

\section{Competing interests}

The author declares that he has no competing interests.

\section{Acknowledgements}

The author gratefully acknowledges the funding support from the German Agency for International Cooperation (GIZ) and the Petroleum Technology Development Fund (PTDF) Nigeria. Many thanks for the contributions of Professor Subhes Bhattacharyya of the Institute of Energy and Sustainable development De Montfort University Leicester; the staff of the Energy Centre at Kwame Nkrumah University of Science and Technology Kumasi-Ghana; The Nigerian Electricity Regulatory Commission (NERC), The Energy Commission of Nigeria (ECN) and staff of the Nigerian Bulk Electricity Trading Plc. (NBET).

\section{Disclaimer}

This article was sponsored by the Nigerian Energy Support Programme (NESP) implemented by the Deutsche Gesellschaft für Internationale Zusammenarbeit (GIZ) GmbH and funded by the German Government and the European Union. The views expressed herein can in no way be taken to reflect the official opinion of the German Government, the European Union or GIZ.

Received: 25 September 2014 Accepted: 11 February 2015

Published online: 24 March 2015

\section{References}

1. Goldemberg J, La Rovere EL, Coelho ST (2004) Expanding access to electricity in Brazil. Energy Sustain Dev 8(4):86-94

2. International Energy Agency-IEA (2011) Energy for all: financing access for the poor, special early excerpt of the world energy outlook 2011. International Energy Agency, Paris, http://www.worldenergyoutlook.org/ media/weowebsite/energydevelopment/weo2011_energy_for_all.pdf. Accessed 18 May 2014

3. International Energy Agency-IEA (2013) Southeast Asia Energy Outlook: World energy outlook special report, International Energy Agency, Paris, at https://www.iea.org/publications/freepublications/publication/SoutheastAsiaEnergyOutlook_WEO2013SpecialReport.pdf. Accessed 20 December 2014

4. International Energy Agency-IEA (2010) Comparative study on rural electrification policies in emerging economies: Key to successful policies, International Energy Agency, Paris, at http://www.iea.org/publications/ freepublications/publication/rural_elect.pdf. Accessed 17 April 2013

5. Bazilian M, Nussbaumer $P$, Rogner HH, Brew-Hammond A, Foster V, Pachauri S, Williams E, Howells M, Niyongabo P, Musaba L, Gallachoir BO, Radka M, Kammen DM (2012) Energy access scenarios to 2030 for the power sector in Sub-Saharan Africa. Util Policy 20(1):1-16

6. National Bureau of Statistics-NBS (2010) Living Standards Measurement Study-Integrated Surveys on Agriculture (LSMS-ISA), at http://www.nigerianstat.gov.ng/pages/download/147. Accessed 17 April 2013

7. Oseni MO (2011) An analysis of the power sector performance in Nigeria. Renew Sustain Energy Rev 15(2011):4765-4774

8. Oseni MO (2012) Households access to electricity and energy consumption pattern in Nigeria. Renew Sustain Energy Rev 16(2012):990-995

9. Energy Sector Management Assistance Program - ESMAP (2005) Nigeria: Expanding access to rural infrastructure: Issues and options for rural electrification, water supply and telecommunication, ESMAP Technical Paper 091. The World Bank, Washington, DC

10. Parshall L, Pillai D, Mohan S, Sanoh A, Modi V (2009) National electricity planning in settings with low pre-existing grid coverage: development of a spatial model and case study of Kenya. Energy Policy 37:2395-2410 
11. Haanyika CM (2006) Rural electrification policy and institutional linkages. Energy Policy 34:2977-2993

12. Modi V, Adkins E, Carbajal J, Shepa S (2013) Liberia power sector capacity building and energy master planning, Final Report. Phase 4: National Electrification Master Plan. http://modi.mech.columbia.edu/wpcontent/ uploads/2013/09/LiberiaEnergySectorReform_Phase4Report-Final_2013-08. pdf. Accessed 18 July 2014

13. Ghosh D, Sagar A, Kishore WN (2006) Scaling-up biomass gasifier use: an application-specific approach. Energy Policy 34:1566-1582

14. Abeygunawardana A (2011) Experiences on off-grid programs in Sri-Lanka. Paper presented at the Workshop on off-grid access system in South Asia; New Delhi, 7 January 2011 at http://www.dmu.ac.uk/documents/ technology-documents/research-faculties/oasys/project-activities/ decentralised-off-grid-electricity-generation/oasys-workshop-report.pdf. Accessed 27 February 2015

15. Palit D, Chaurey A (2013) Off-Grid Rural Electrification Experiences from South Asia In: Bhattacharyya SC (ed) Rural Electrification through decentralized Off-grid Systems in Developing Countries, Green Energy and Technology. Springer-Verlag, London, pp 75-104

16. ArcGIS software (2010) at http://www.esri.com/software/arcgis/. Accessed 17 June 2013

17. Kemausuor F, Brew-Hammond A, Adu-Poku I, Obeng YG, Duker A, Annor F, Baomah F, Ladzagla D (2012) GIS-based support for implementing policies and plans to increase access to energy services in Ghana., http://www.euei-pdf.org/sites/default/files/files/field_pblctn_file/EUEl\% 20PDF_Ghana_\%20GIS\%20based\%20support\%20for\%20Energy\%20 Access_Report_Mar\%202012_EN.pdf, Accessed 2 April 2014

18. Kemausuor F, Obeng YG, Brew-Hammond A, Duker A (2011) A review of trends, policies and plans for increasing energy access in Ghana. Renew Energy Sustain Energy Rev 15:5143-5154

19. Agence Senegalaise d'Electrification Rurale (2007) Costing for national electricity interventions to increase access to energy, health services and education, Senegal, Final Report. World Bank, Washington DC

20. Sanoh A, Parshall P, Sarr OU, Kum S, Modi V (2012) Local and national electricity planning in Senegal: scenarios and policies. Energy Sustain Dev 16:13-25

\section{Submit your manuscript to a SpringerOpen ${ }^{\circ}$ journal and benefit from:}

- Convenient online submission

- Rigorous peer review

- Immediate publication on acceptance

- Open access: articles freely available online

- High visibility within the field

- Retaining the copyright to your article

Submit your next manuscript at $\gg$ springeropen.com 